Литвин В.В., Таран І.О., Кононенко К.С.

Начіональний технічний університет «Дніпровська політехніка», м. Дніпро, Украӥна

\title{
ОБГРУНТУВАННЯ ЕФЕКТИВНОСТІ ЗАСТОСУВАННЯ КІЛЬЦЕВОГО РУХУ НА ВУЛИЧНО-ДОРОЖНІЙ МЕРЕЖІ М. ДНІПРО У ПРОГРАМНОМУ СЕРЕДОВИЩІ РТV VISSIM
}

\footnotetext{
В сучасних умовах одним із найбільш дієвих методів зниження аварійності та запобігання ДТП на перехрестях $є$ облаштування сучасних кільцевих перетинів. Виконано аналіз зарубіжного досвіду щодо ефективності запровадження кільцевого руху та наведені основні елементи сучасного кільцевого перетину. У якості об'єкту дослідження на вулично-дорожній мережи м. Дніпро було обране перехрестя вул. Набережна Заводська - вул. Павлова із обгрунтуванням критеріїв його вибору. Інтенсивності транспортних потоків на перехресті були отримані методом натурних обстежень для ранкової години «пік» 3 700-800. У якості інструментарію моделювання був застосований програмний продукт PTV Vissim 11. Згідно запропонованого авторами алгоритму були розроблені дві імітаційні транспортні моделі перехрестя вул. Набережна Заводська вул. Павлова із регульованим та кільцевим рухом. Якісний аналіз результатів моделювання дозволяє зробити висновок, що організація регульованого руху призводить до утворення суттєвих заторів. Для подальшого аналізу авторами був обраний перелік із 7 показників, які $є$ найбільш значущими для оцінки ефективності запровадження кільцевого руху. Наведені їх абсолютні (за результатами моделювання) та розраховані відносні значення. Результати моделювання, свідчать, що застосування кільцевого руху сприяє підвищенню ефективності руху за всіма обраними показниками з діапазоні від 3\% до 92\%. Значення запропонованого авторами комплексного показника ефективності для кільцевого руху становить 1,00, а для світлофорного 0,34, таким чином загальна ефективність запропонованих рішень для обраного об'єкту дослідження склала $66 \%$.

Ключові слова: вулично-дорожня мережа, безпека руху, конфліктні точки, кільцеве перехрестя, імітаційне моделювання, довжина затору, середня швидкість, час затримки, PTV Vision VISSIM.
}

\section{ВСТУП}

Удосконалення умов руху автомобільного транспорту в сучасних містах вимагає застосування цілого комплексу архітектурно планувальних і технічних заходів. У той час як реалізація дорожніх та архітектурно-планувальних заходів вимагає, окрім значних капіталовкладень, досить тривалого періоду часу реалізації, заходи організації дорожнього руху (ОДР) можуть забезпечувати швидкий ефект, а в ряді випадків виступають у ролі єдиного засобу вирішення транспортних проблем сучасного міста. Значне зростання кількості індивідуального транспорту (яке спостерігається останнім часом) i обсягів перевезень призводить до підвищення інтенсивності руху та створює додаткове навантаження на основні елементи вулично-дорожньої мережі (ВДМ), більшість 3 яких побудовані ще в середині минулого століття. Внаслідок цього виникають черги і затори, збільшуються транспортні затримки, що призводить до зниження швидкості сполучення, невиправданих перевитрат палива і підвищення зносу вузлів i агрегатів транспортних засобів.

Одним із головних критеріїв ефективності функціонування ВДМ є забезпечення безконфліктного існування всіх учасників дорожнього руху в обмеженому просторі. Питання безпеки дорожнього руху $\epsilon$ особливо актуальним для Україні, оскільки, за даними офіційної статистики, на дорогах країни кожні 18 хвилин трапляється ДТП, а через кожні 117 хвилин у аваріях гине людина. Високе зниження пропускної здатності і безпеки руху найчастіше виникає в зоні перехресть, особливо на ділянках злиття $\mathrm{i}$ переплетення транспортних потоків, де відбувається зміна напряму руху. Світлофорне регулювання на перехресті, як метод організації дорожнього руху, заснований на маршрутному поділі потоків у часі, вже давно не $\epsilon$ гарантом безпеки дорожнього руху і не забезпечує необхідну пропускну здатність. У зв'язку з цим виникає гостра необхідність у перегляді діючих підходів до проектування вулично-дорожньої мережі, підтримці впровадження інтелектуальних систем транспортного моделювання та інших сучасних методів планування дорожнього руху [1]. Аналіз практики організації дорожнього руху говорить про існування ефективних методів підвищення безпеки руху, які застосовуються для перетинів в одному рівні. Одним із таких методів є організація кільцевого руху. 


\section{АНАЛІЗ ЛІТЕРАТУРНИХ ДАНИХ ТА ПОСТАНОВКА ПРОБЛЕМИ}

За транспортно-планувальною характеристикою і способом організації дорожнього руху усі вузли можна розділити на наступні групи: нерегульовані; регульовані; саморегульовані.

Регульоване перехрестя є одним 3 найпоширеніших типів вузлів вулично-дорожньої мережі міста. Основні затори і затримки транспорту виникають саме на регульованих перехрестях, які і обмежують пропускну здатність вулиць та доріг [2]. Тому якість організації дорожнього руху на регульованих перехрестях в першу чергу впливає на показники функціонування транспортної мережі та ефективність транспортних процесів перевезень [3]. Протягом багатьох десятиріч світлофорне регулювання залишалося основним методом організації дорожнього руху на багатьох видах пересічень. Але в сучасних умовах, які характеризуються динамічними знакозмінними навантаженнями на ВДМ, фіксоване (та в деяких умовах навіть адаптивне) управління світлофорними об'єктами не завжди буває ефективним і виправдовує своє застосування. Як було зазначено вище, основними недоліками світлофорного регулювання $€$ значне скорочення пропускної здатності перехресть та зниження швидкості руху. Також зазначимо, що згідно із відомостями, наданими Патрульною полицею України, більшість ДТП у містах України відбувається саме на регульованих перехрестках (рисунок 1) [4].

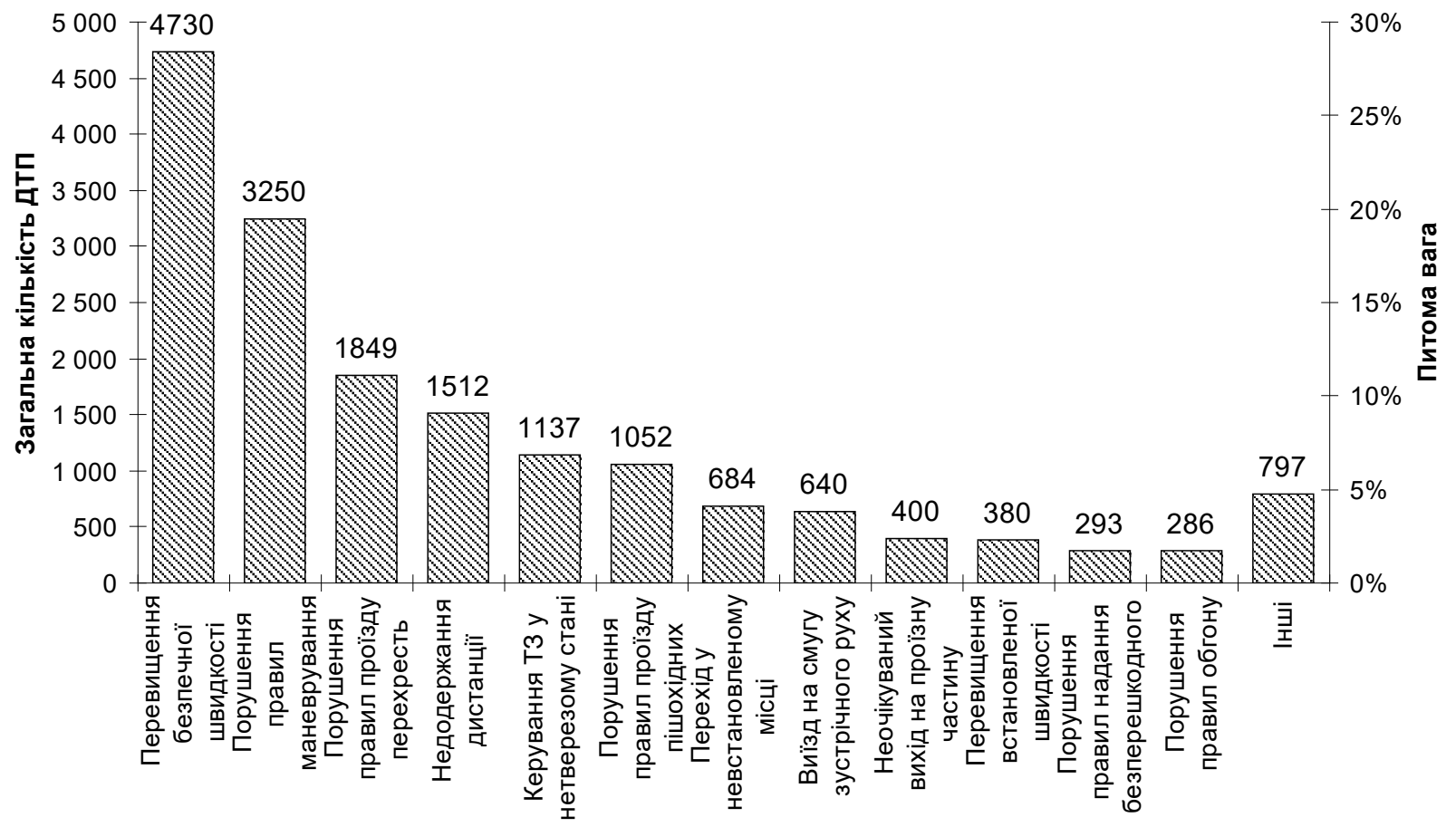

Рисунок 1 - Аналіз причин скоєння ДТП із постраждалими в Україні за період з 01.01.2018 по 31.12.2018

Досвід зарубіжної практики засвідчує, що одним з основних способів підвищення безпеки руху на перехрестях є заспокоєння руху. Заспокоєння руху - це методи створення фізичних та візуальних перешкод руху на великій швидкості на необхідних ділянках. Одним із найбільш дієвих методів зниження аварійності та запобігання ДТП безпосередньо на перехрестях $є$ облаштування сучасних кільцевих перетинів малого і середнього діаметрів, які позначаються терміном roundabout [5].

У багатьох країнах Західної Європи, Північної Америки та Австралії ефективність застосування кільцевих перетинів даного типу переконливо підтверджується зниженням всіх показників аварійності, особливо зниженням тяжкості ДТП і зменшенням кількості ДТП із загиблими. Це пояснюється:

- значним зменшенням кількості конфліктних точок (Рисунок 2);

- геометричними параметрами, які призводять до зниження швидкості руху на перетинах типу roundabout;

- $\quad$ поліпшенням умов руху пішоходів - скорочується протяжність переходів через проїжджі частини перетину.

Основні елементи сучасного кільцевого перетину наведені на рисунку 3. 

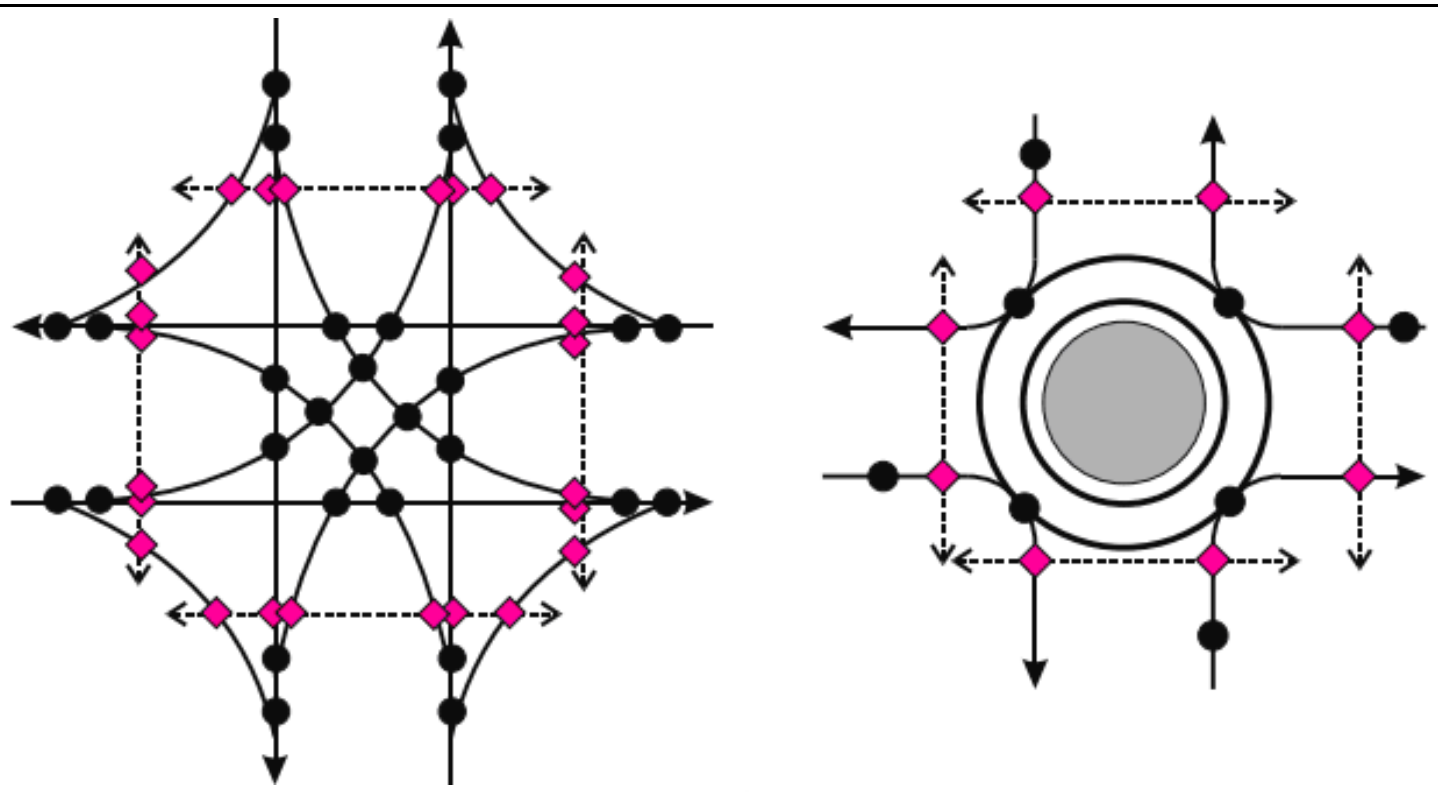

- 32 конфліктні точки «автомобіль - автомобіль»

- 24 конфліктні точки «автомобіль - пішохід»

- 8 конфліктні точки «автомобіль - автомобіль»

- 8 конфліктні точки «автомобіль - пішохід»

Рисунок 2 - Кількість конфліктних точок на нерегульованому і кільцевому перетинах

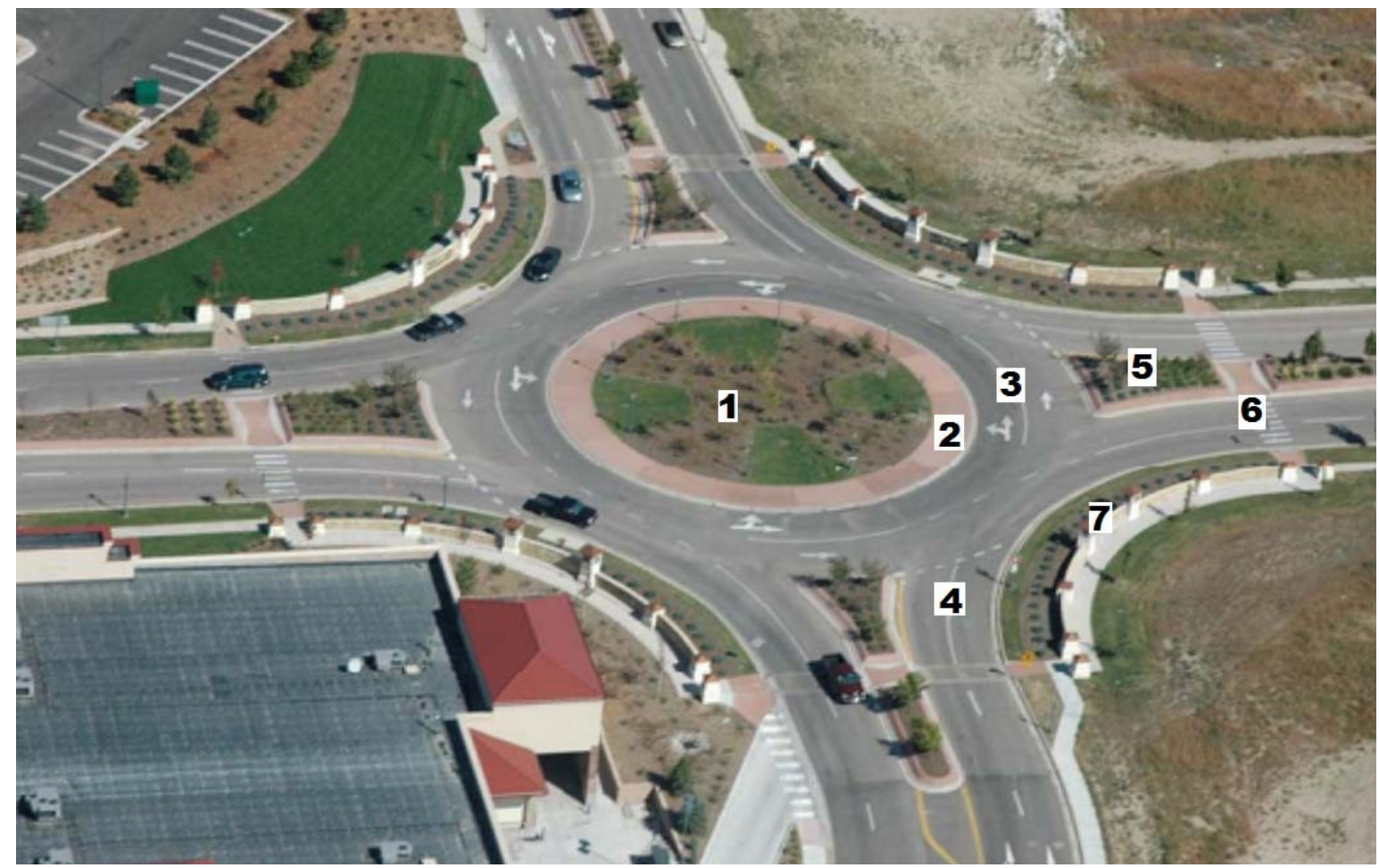

Рисунок 3 - Основні елементи сучасного кільцевого перетину

(1 - припіднятий центральний острівець; 2 - апрон (apron, truck apron); 3 - кільцева проїжджа частина; 4 - двосмуговий вхід на кільцеве перетин із розміткою yield (поступися дорогою); 5 - припіднятий розділювальний острівець (splitter island); 6 - пешеходный переход; 7 - ландшафтний буфер

Сам термін roundabout з'явився в Британії ще в 1929 році в Міністерстві Транспорту та Інституті Планування Міст (the Town Planning Institute). Слід зазначити, що в керівництві по кільцевим перетину штату Флорида (FRG 1996) був введений новий термін «Сучасний кільцевий перетин» (modern roundabout), який став часто використовуватися в технічній літературі і періодиці. При цьому під сучасним розуміється кільцевий перетин, який задовольняє певним вимогам (таблиця 1) [6]. 


\begin{tabular}{|c|c|c|}
\hline Характеристика & Сучасний кільцевий перетин & Класична кільцева розв'язка \\
\hline Керування на вході & Знак «уступи дорогу» & $\begin{array}{c}\text { Знак «рух без зупинки } \\
\text { заборонено» або пріоритетність } \\
\text { потоку, що вливається } \\
\end{array}$ \\
\hline Характеристика руху & $\begin{array}{c}\text { Транспортний потік, що рухається } \\
\text { по кільцю має пріоритет відносно } \\
\text { потоку, що вливається }\end{array}$ & $\begin{array}{l}\text { Є місця злиття потоків для } \\
\text { вирішення конфліктів }\end{array}$ \\
\hline $\begin{array}{c}\text { Відхилення від прямолінійного } \\
\text { руху }\end{array}$ & $\begin{array}{c}\text { Використовується для зниження } \\
\text { швидкості }\end{array}$ & $\begin{array}{c}\text { На великих кільцях для основного } \\
\text { потоку не використовується, } \\
\text { забезпечуються високі швидкості }\end{array}$ \\
\hline $\begin{array}{c}\text { Місця для паркування } \\
\text { автомобілів всередині кільця }\end{array}$ & \multirow{2}{*}{ Забороняються } & \multirow{2}{*}{ Допускається на великих кільцях } \\
\hline $\begin{array}{c}\text { Пішохідних перехід через } \\
\text { центральний острівець }\end{array}$ & & \\
\hline Рух по кільцю & $\begin{array}{c}\text { На міні-кільцях лівобічні маневри } \\
\text { можуть виконуватися через } \\
\text { центральний острівець }\end{array}$ & $\begin{array}{c}\text { Весь потік рухається навколо } \\
\text { центрального острівця }\end{array}$ \\
\hline
\end{tabular}

Розміри сучасних кільцевих перетинів (діаметром 20...30 м) і їх низька вартість дозволяють широко застосовувати їх на вулично-дорожньої мережі сучасних міст, що є великою перевагою. Накопичений світовий досвід експлуатації доріг з кільцевими перетинами показав, що вони при дотриманні комплексу вимог до їх планування і методам організації руху можуть працювати досить ефективно. Крім того, організація кільцевого руху, повністю або частково виключає місця перетину транспортних потоків, замінюючи їх послідовним злиттям або розподілом, і таким чином сприяє суттєвому підвищенню безпеки руху та зниження тяжкості дорожньо-транспортних пригод. Згідно даним міжнародної статистики [7] їх застосування призводить до загального зниження ДТП на 40-80\%; на 90\% скорочується кількість ДТП із смертельним результатом, на 75\% - ДТП з пораненими, на 35\% число подій, пов'язаних із наїздами на пішоходів, і на $10 \%$ із наїздами на велосипедистів. За показником тяжкості наслідків ДТП кільцеві перетини найбільш ефективні на позаміських автомобільних дорогах, де реєструється зниження кількості загиблих на перетинах в одному рівні більш ніж в 2 рази. На міських кільцевих перетинах даний показник становить 18-20\% [8].

Незважаючи на перераховані вище переваги, у вітчизняній практиці дорожнього проектування сучасні кільцеві перетини не отримали належного застосування в першу чергу у зв'язку із недостатньо розвиненою нормативно-методичною базою. Однією із альтернатив вирішення цієї проблеми $\epsilon$ запозичення моделей, розроблених в Європейських країнах, проте в цьому випадку існує велика імовірність виникнення неточності оцінки через відмінності внаслідок різних принципів проектування, а також манери водіння. Перераховані вище передумови, засвідчують про актуальність задачі вивчення умов застосування сучасних кільцевих перетинів на ВДМ середніх та великих міст України 3 метою обгрунтування їх оптимальних геометричних та технічних параметрів.

Сучасний науковий підхід до планування та аналізу складних транспортних систем (в т.ч. i дорожнього руху) неможливо уявити без застосування інструментів імітаційного моделювання. На сьогоднішній день в розвинених країнах Європейського Союзу основним інструментом моделювання дорожнього руху є програмний комплексу PTV VISSIM, який дозволяє створювати імітаційні моделі елементів ВДМ міста будь якої складності із подальшим аналізом наслідків сумісної взаємодії транспортних та пішохідних потоків, засобів регулювання та громадського транспорту.

\section{ЦІЛЬ ТА ЗАДАЧІ ДОСЛІДЖЕННЯ}

Метою роботи є обгрунтування ефективності застосування кільцевого руху на обраному об'єкті вулично-дорожньої мережі м. Дніпро. Для реалізації мети дослідження необхідно провести обстеження транспортних потоків; у програмному середовищі PTV VISSIM розробити імітаційні транспортні моделі перехрестя із регульованим, та кільцевим рухом; навести результати моделювання; обрати кількісні показників, за якими будуть порівнюватися обрані схеми транспортного руху; запропонувати структуру комплексного критерію для оцінки ефективності руху на окремому перехресті. 


\section{РЕЗУЛЬТАТИ ДОСЛІДЖЕНЬ}

У якості об'єкту дослідження на ВДМ м. Дніпро було обране перехрестя вул. Набережна Заводська - вул. Павлова, яке відноситься до Т-образного типу і на якому організована схема руху із трьома фазами роз'їзду. Зовнішній вигляд перехрестя, його схема, а також діючі фази роз’їзду наведені на рисунках 4-8 відповідно.

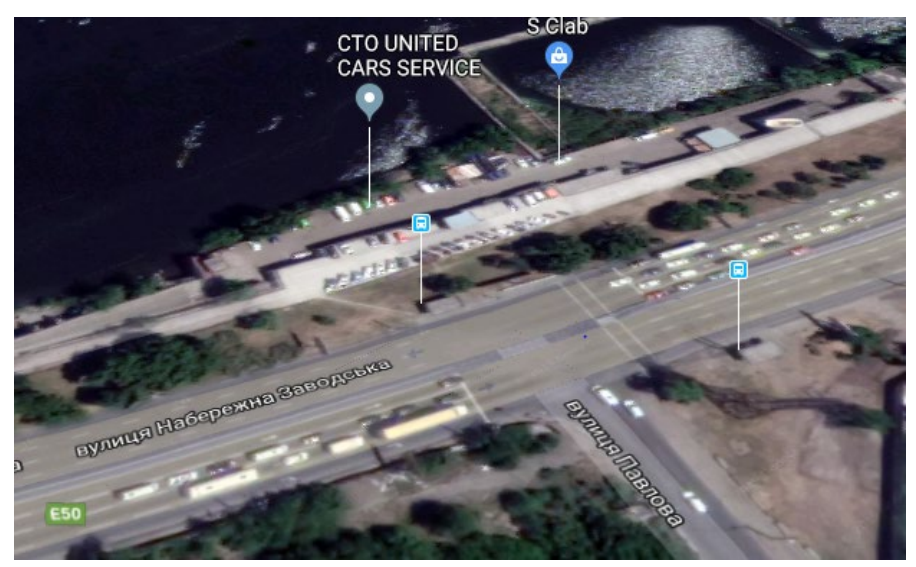

Рисунок 4 - Зовнішній вигляд Т-го перехрестя вул. Набережна Заводська - вул. Павлова

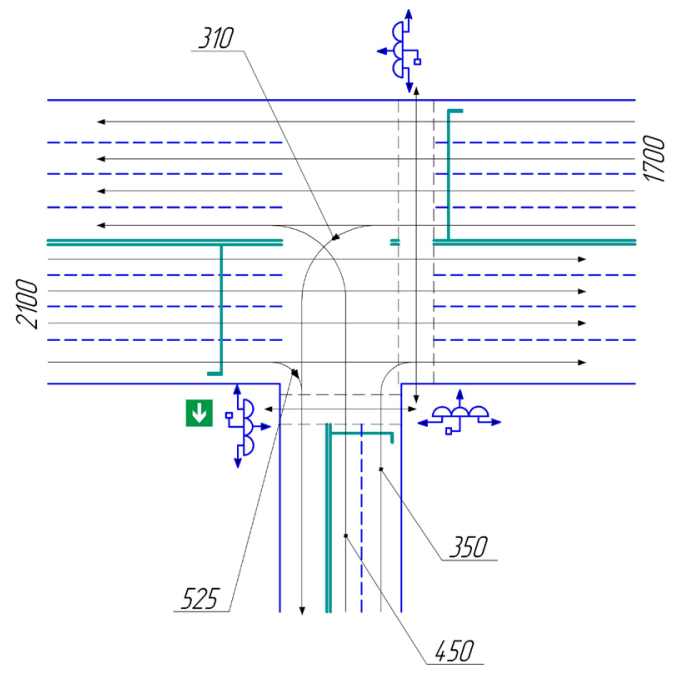

Рисунок 5 - Схема перехрестя

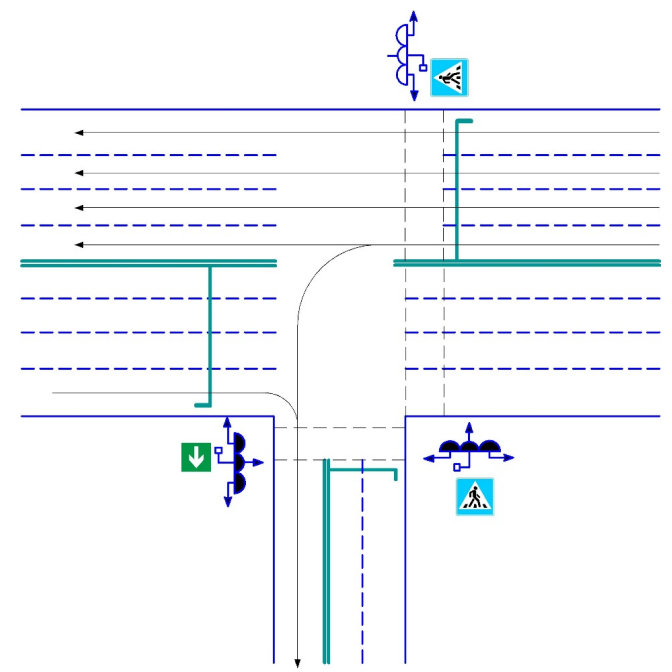

Рисунок 7 - Друга фаза роз'їзду

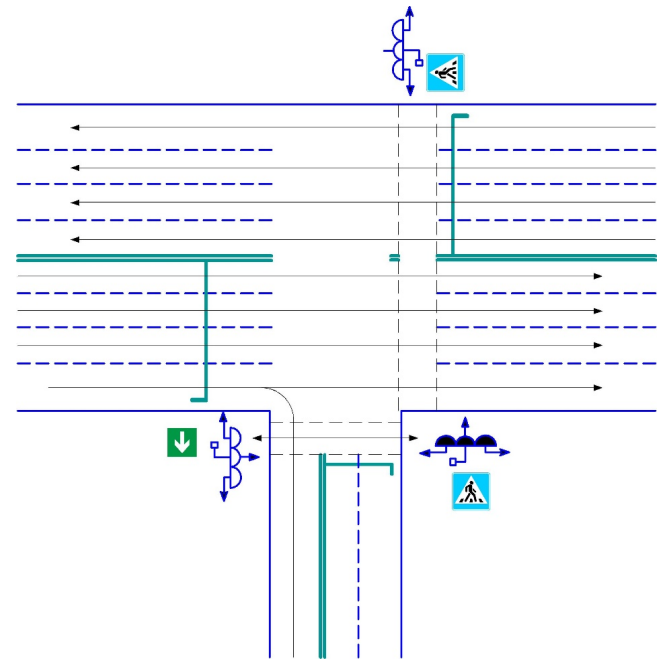

Рисунок 6 - Перша фаза роз’їзду

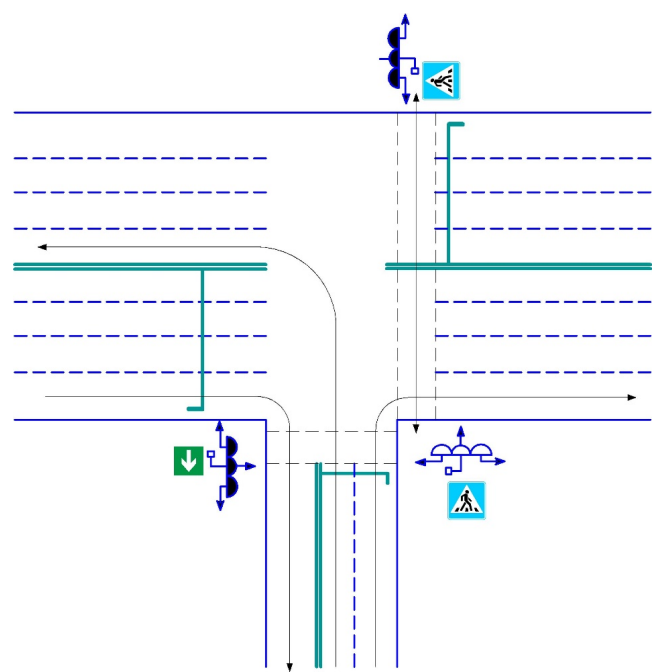

Рисунок 8 - Третя фаза роз'їзду 
Вибір перехрестя вул. Набережна Заводська - вул. Павлова у якості об'єкту дослідження пояснюється високими інтенсивностями руху транспортних засобів (у години «пік» понад 2000 авт/год), великою питомою вагою вантажного та пасажирського транспорту (по деяких напрямах руху до $30 \%$ ) та підвищеною аварійністю (за останній рік на ньому трапилося 7 ДПТ, два 3 яких із тяжкими наслідками). Тривалість світлофорного циклу 110 с. Особливістю перехрестя є наявність трисекційного світлофору 3 додатковою секцією («зелена стрілка») при повороті праворуч на вул. Павлова (рисунок 5-8).

Інтенсивності транспортних потоків на перехресті були отримані методом натурних обстежень для ранкової години «пік» $37^{00}-8^{00}$. Було встановлено, що інтенсивності вхідних потоків за напрямком руху №1 (ж/м Парус $\rightarrow$ Центр) становлять 2100 авт./год., за напрямком руху №2 (Центр $\rightarrow$ ж/м Парус) - 1700 авт./год., а за напрямком руху №3 (з вул. Павлова) - 800 авт./год. Епюра інтенсивності транспортних потоків також наведена на схемі перехрестя (рисунок 5).

У якості інструментарію моделювання був застосований програмний продукт PTV Vissim (64 bit) 11 (Студентська версія). Слід зауважити, що «Студентська версія» майже не має функціональних обмежень, але дозволяє досліджувати створені об'єкти лише протягом 600 с. Таким чином, отримані нижче результати моделювання є чинними для проміжку часу, який складає 10 хв. Враховуючи тривалість світлофорного циклу на перехресті вул. Набережна Заводська - вул. Павлова, який складає 110 с., автори вважають дане обмеження припустимим, а отримані результати мають право бути екстрапольовані спроектовані і на більш тривалі проміжки часу.

В роботі [1] авторами був запропонований алгоритм створення моделі перехрестя у програмному середовищі PTV VISSIM, який наведено на рисунку 9.

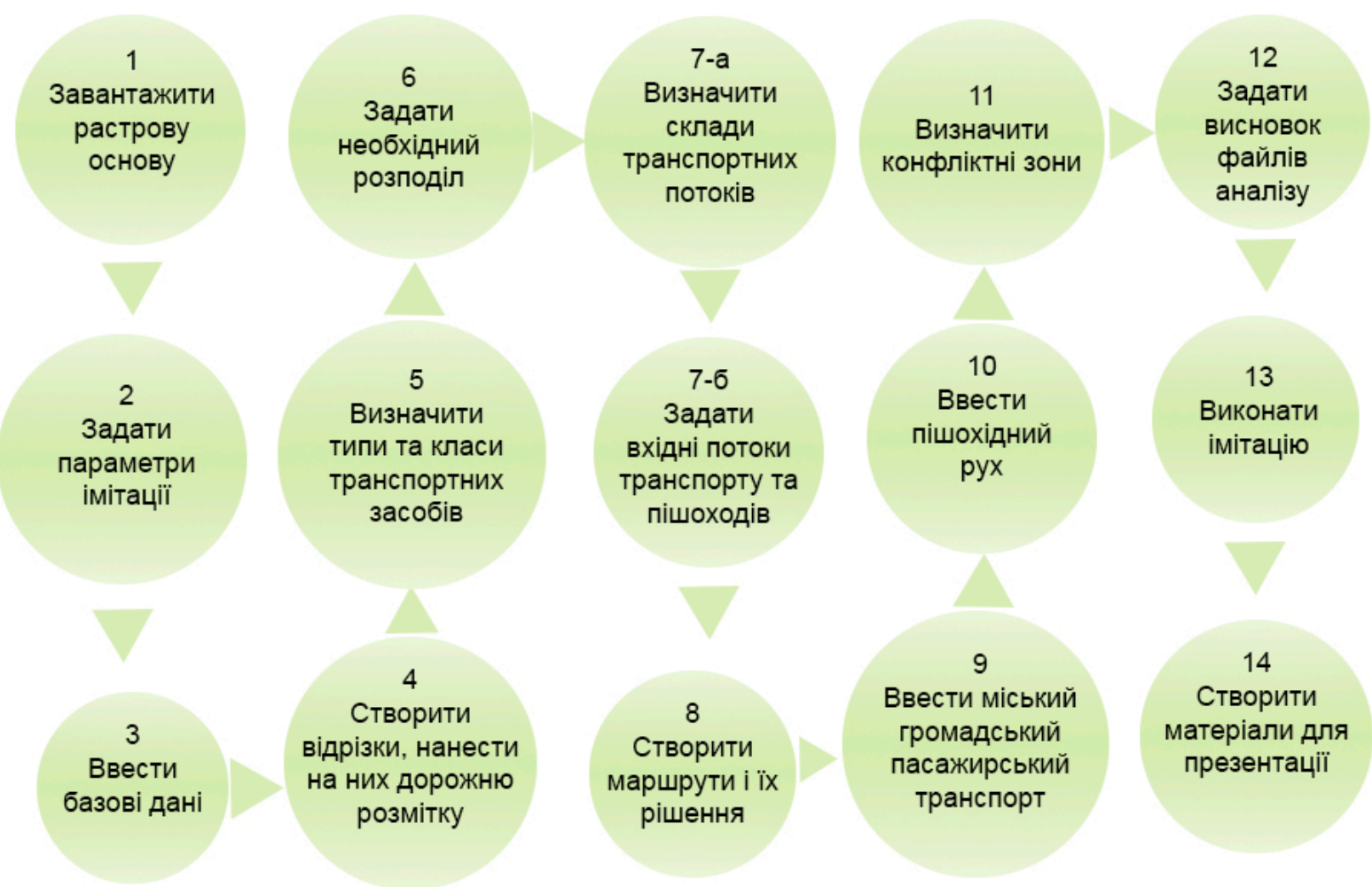

Рисунок 9 - Алгоритм створення моделі перехрестя у програмному середовищі PTV VISSIM

Згідно запропонованого алгоритму були розроблені дві імітаційні транспортні моделі перехрестя вул. Набережна Заводська - вул. Павлова із регульованим (рисунок 10) та кільцевим рухом (рисунок 11). Процес імітації руху транспортних засобів на цих перехрестях наведено на рисунках 12 та 13 відповідно. Навіть якісний аналіз результатів моделювання дозволяє зробити висновок, що організація регульованого руху призводить до утворення суттєвих заторів. Можливості кількісного аналізу 
транспортного руху у PTV VISSIM наведено на рисунку 14. В таблиці 2 наведені основні характеристики руху, які розраховуються у PTV VISSIM протягом імітації.

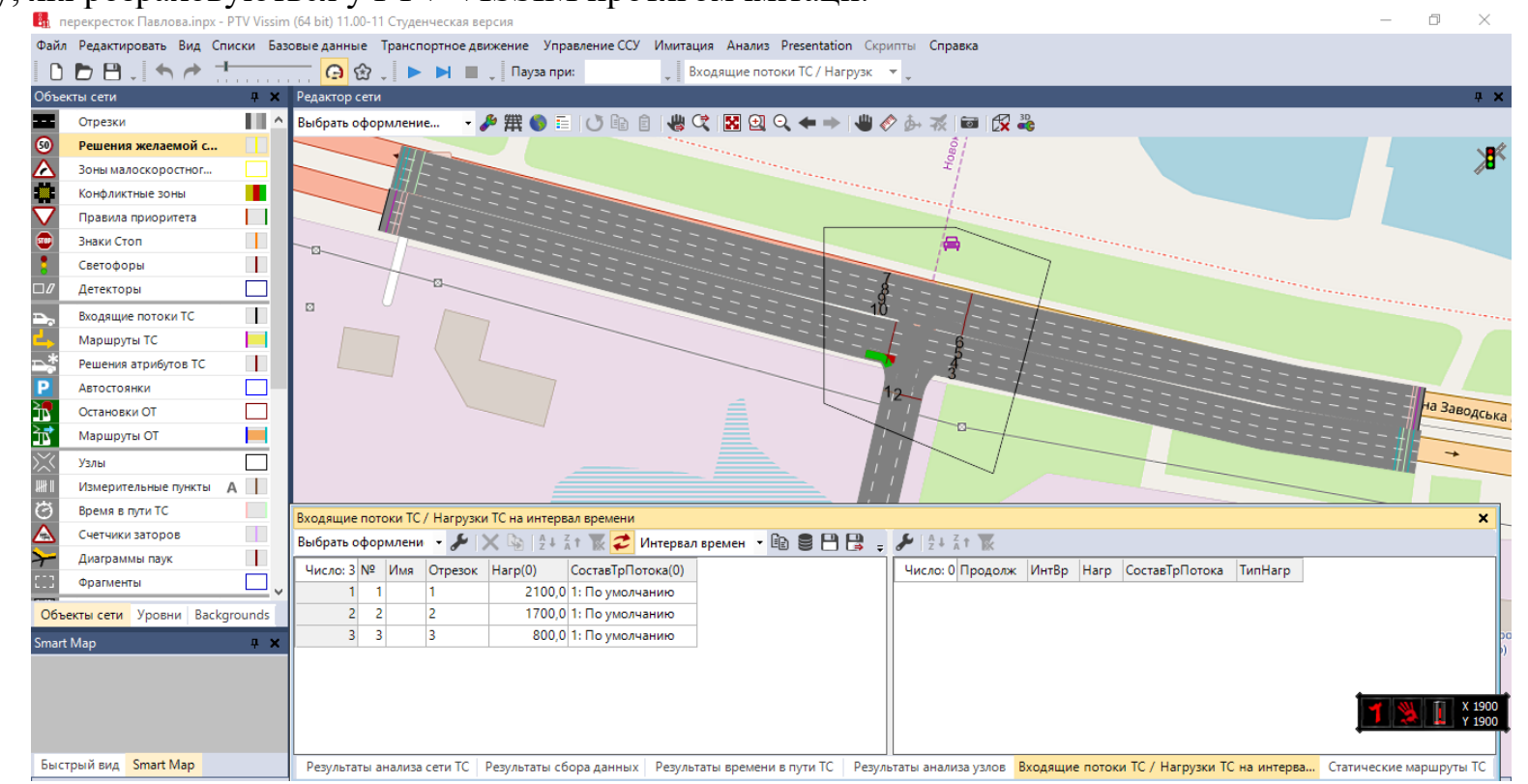

Рисунок 10 - Модель перехрестя вул. Набережна Заводська - вул. Павлова із регульованим рухом

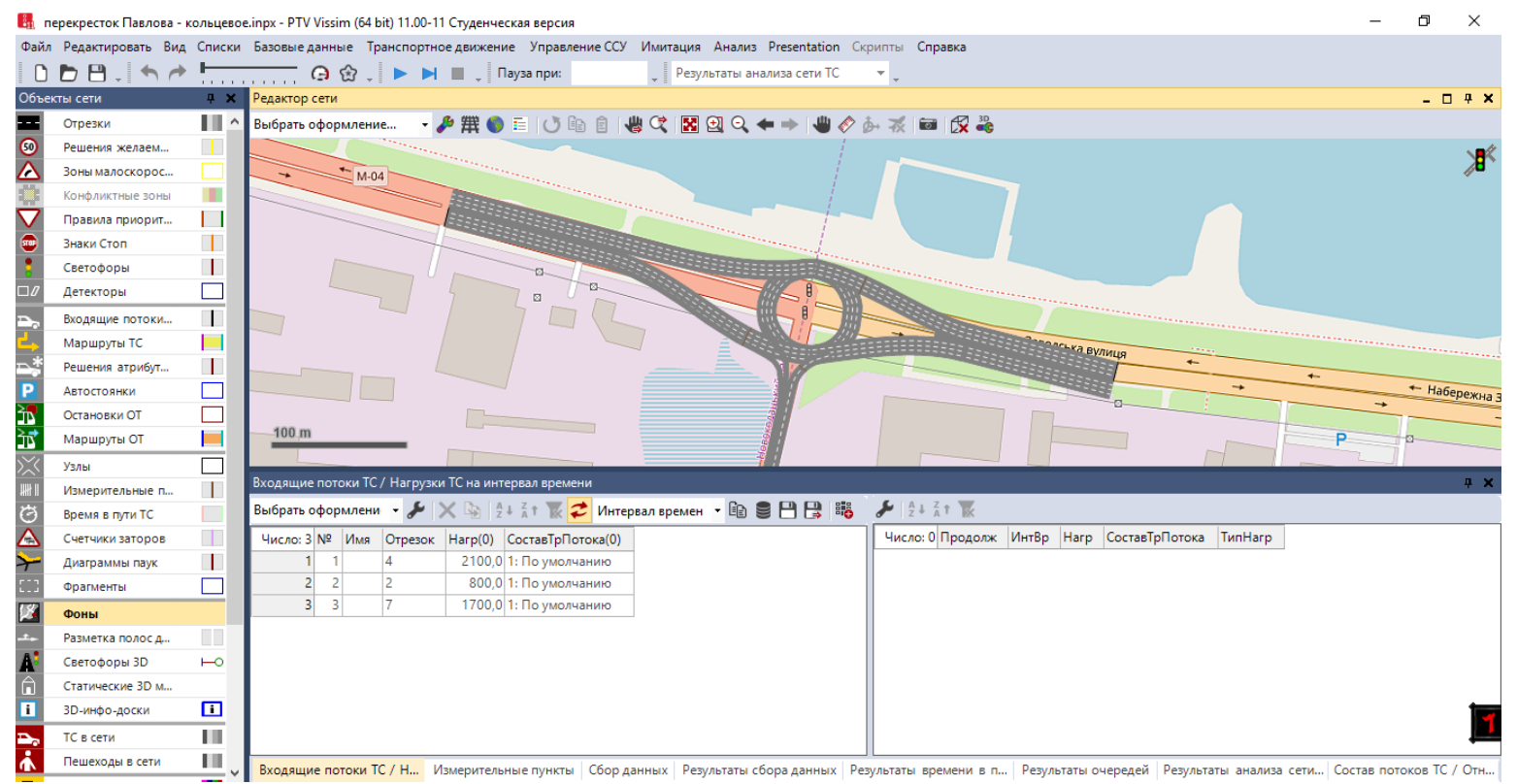

Рисунок 11 - Моделі перехрестя вул. Набережна Заводська - вул. Павлова із кільцевим рухом

Виходячи із рекомендацій наданих у роботі [9] (таблиця 3) та у роботі [10] авторами був обраний перелік із 7 показників, які на їх думку є найбільш значущими для оцінки ефективність запровадження кільцевого руху. Абсолютні (за результатами моделювання) та відносні значення обраних показників наведені у таблиці 4.

Для комплексної оцінки ефективності руху на окремому перехресті автори пропонують використовувати функціонал наступного виду:

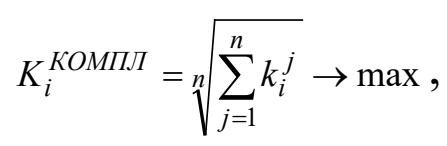


де $k_{i}^{j}$ - відносна величина $j$-го показника ефективності при $i$-му варіанті організації дорожнього руху; $n$ - кількість показників, що враховуються.

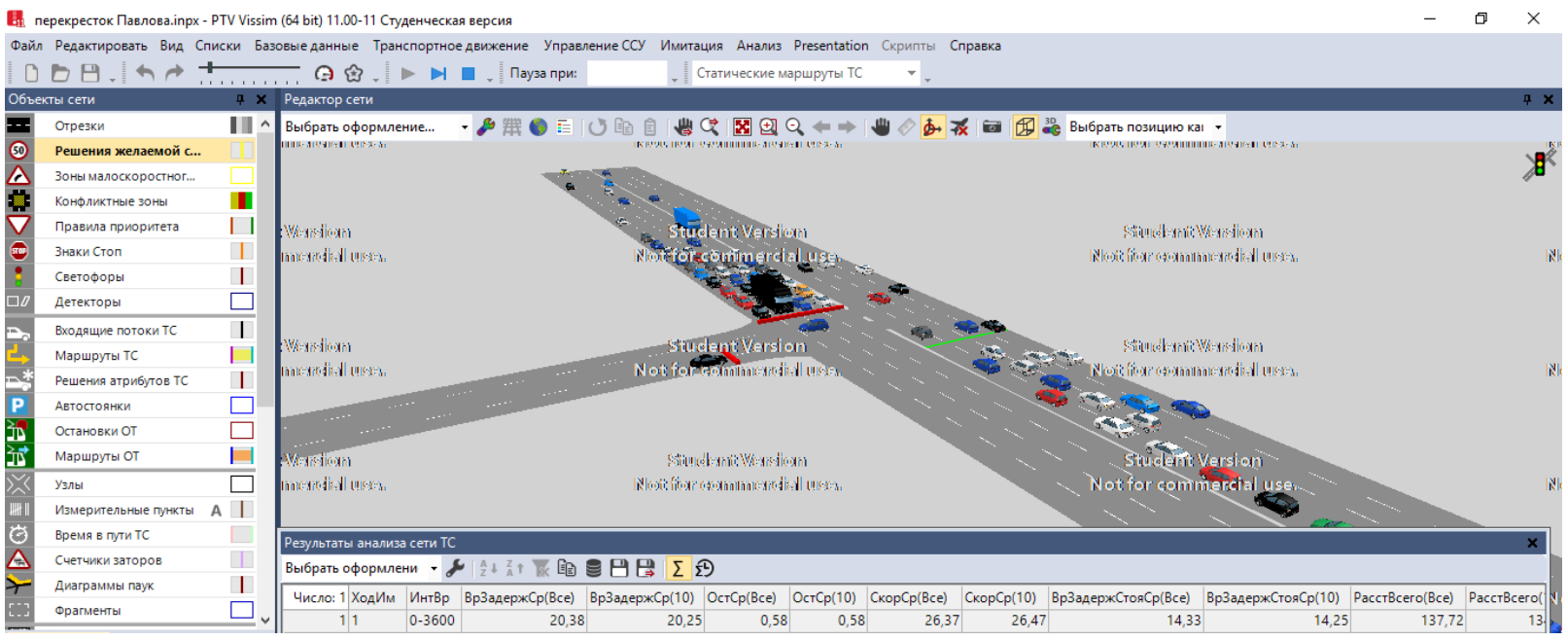

Рисунок 12 - Процес імітації руху транспортних засобів на перехресті із регульованим рухом

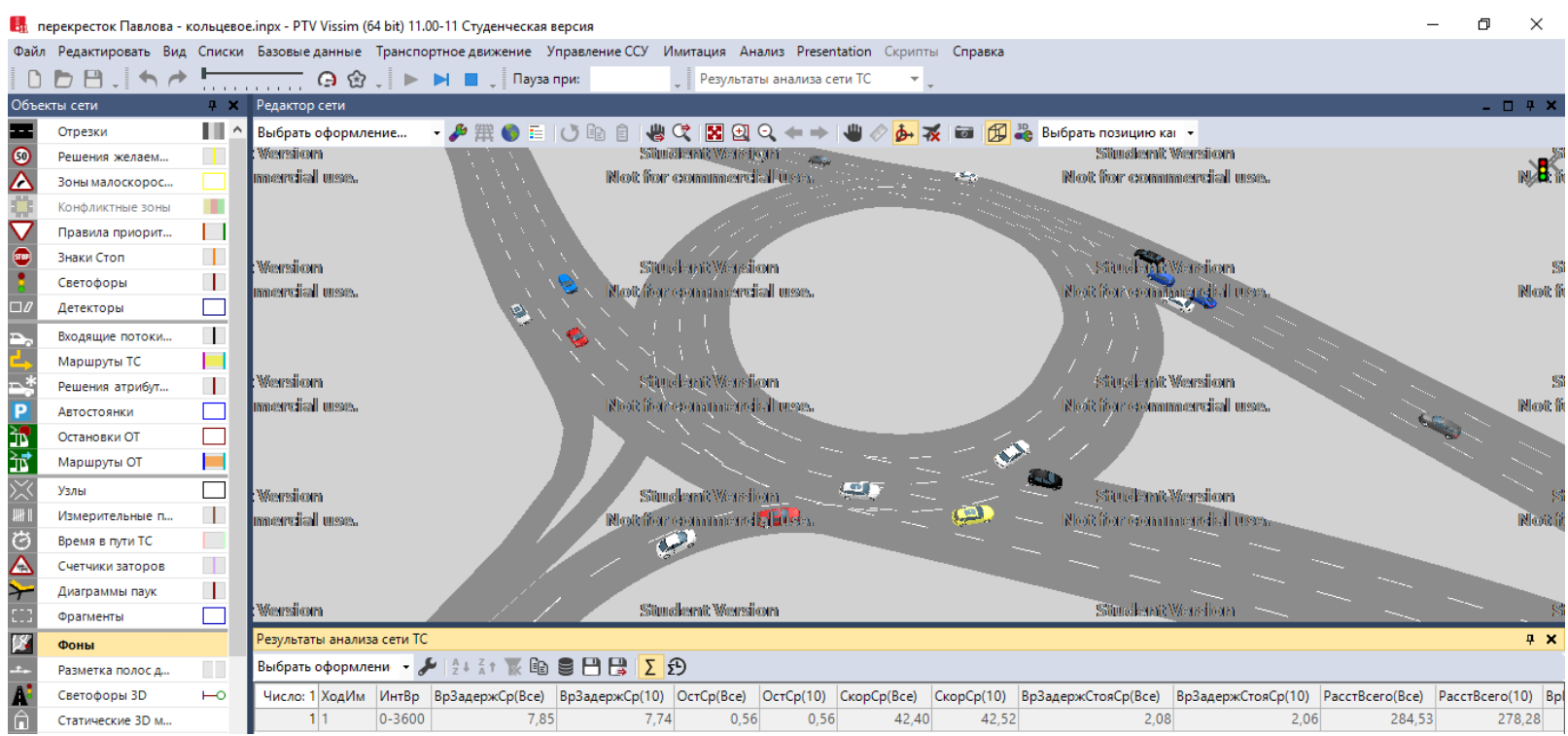

Рисунок 13 - Процес імітації руху транспортних засобів на перехресті із кільцевим рухом 


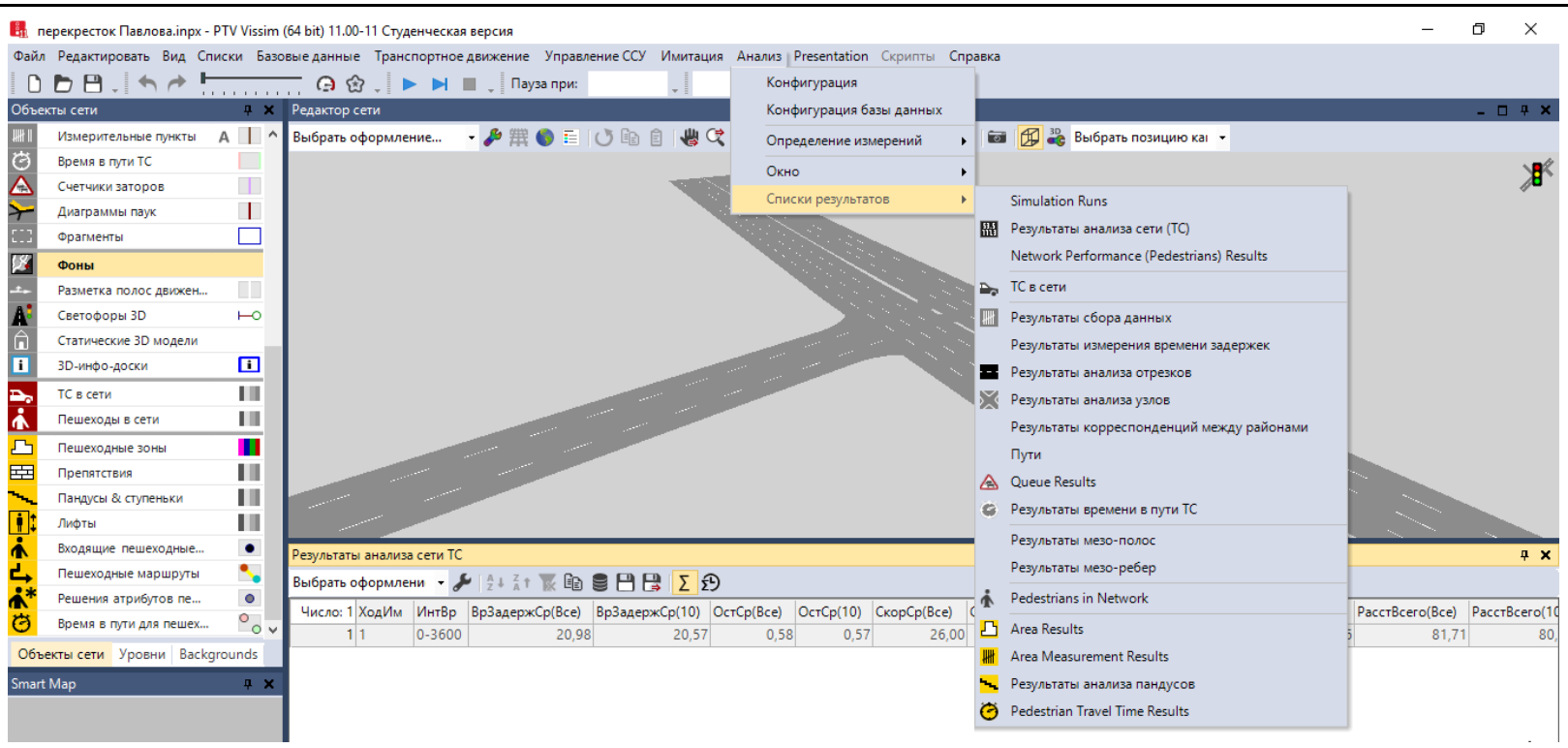

Рисунок 14 - Можливості кількісного аналізу транспортного руху у PTV VISSIM

Таблиця 2 - Основні характеристики транспортного руху, які розраховуються у PTV VISSIM

\begin{tabular}{|c|l|l|}
\hline$№$ п/п & \multicolumn{1}{|c|}{ Назва функції у РTV VISSIM } & \multicolumn{1}{|c|}{ Зміст функції } \\
\hline 1 & Час затримки (середнє значення) & Середній час затримки Т3 \\
\hline 2 & Зупинки (середне значення) & Середня кількість зупинок Т3 \\
\hline 3 & Швидкість (середня) & Середня швидкість \\
\hline 4 & Час простою & Середній час простою Т3 \\
\hline 5 & Відстань & Загальна відстань всіх Т3 \\
\hline 6 & Час в дорозі & Загальний час в дорозі всіх Т3 \\
\hline 7 & Загальний час затримки (всього) & Повний час затримки Т3 \\
\hline 8 & Зупинки (всього) & Загальна кількість зупинок Т3 \\
\hline 9 & Час простою (всього) & Загальний час простою Т3 \\
\hline 10 & ТЗ (акт) & Загальна кількість авто за час імітації \\
\hline 11 & Прискорення & Середнє прискорення авто \\
\hline 12 & Час в заторі & Час в заторі всіх Т3 \\
\hline 13 & Ступінь заповнення & Час, за який був заданий вимірювальний пункт \\
\hline 14 & Подоланий відрізок дороги & Відстань, яку подолав один Т3 \\
\hline 15 & Люди & Кількість людей в системі \\
\hline 16 & Довжина затору (максимальна) & Максимальна довжина затору \\
\hline 17 & Рівень обслуговування Т3 & Значення рівня обслуговування від 1-6 \\
\hline 18 & Емісія СО & Кількість монооксида вуглецю на 1 Т3 \\
\hline 19 & Емісія NО & Кількість монооксидів азоту \\
\hline 20 & Емісія VОС & Кількість летючих органічних з’єнань \\
\hline 21 & Витрати палива & Витрати палива \\
\hline 22 & Щільність & Щільність потоку \\
\hline 23 & Навантаження & Кількість Т3 за годину \\
\hline & & \\
\hline
\end{tabular}

Таблиця 3 - Аналіз відповідності мети керування дорожнім рухом та критеріями якості

\begin{tabular}{|c|c|}
\hline МЕТА КЕРУВАННЯ & КРИТЕРІЇ ЯКОСТІ КЕРУВАННЯ \\
\hline Гарантування безпеки руху & - Рівень аварійності на ВДМ \\
\hline Підвищення рівня обслуговування учасників руху & $\begin{array}{ll}\text { - } & \text { Тривалість затримки } \\
\text { - } & \text { Середня швидкість руху } \\
\text { - } & \text { Кількість зупинок } \\
\text { - } & \text { Довжина черги перед перехрестям }\end{array}$ \\
\hline
\end{tabular}


(с) Литвин В.В., Таран I.О., Кононенко К.С. 2019

\begin{tabular}{|c|c|}
\hline & - Експлуатаційні витрати \\
\hline Підвищення пропускної здатності ВДМ & - Рівень використання пропускної здатності ВДМ \\
\hline Зменшення шкідливого впливу на довкілля & $\begin{array}{l}\text { - } \text { Рівень забруднення відпрацьованими газами } \\
\text { - } \quad \text { Витрати палива }\end{array}$ \\
\hline Надійність керування & $\begin{array}{ll}\text { - } & \text { Максимальна швидкість руху } \\
\text { - } & \text { Параметр нерівномірності руху } \\
\end{array}$ \\
\hline
\end{tabular}

Таблиця 4 - Обрані для подальшого аналізу результати моделювання

\begin{tabular}{|c|c|c|c|c|c|c|}
\hline \multirow{3}{*}{ № ח/П } & \multirow{3}{*}{ Показник } & \multicolumn{4}{|c|}{ Значення показника } & \multirow{3}{*}{$\begin{array}{c}\text { Ефект, } \\
\%\end{array}$} \\
\hline & & \multicolumn{2}{|c|}{ Регульований рух } & \multicolumn{2}{|c|}{ Кільцевий рух } & \\
\hline & & абсолютне & відносне & абсолютне & відносне & \\
\hline 1 & Середній час затримки Т3, с & 21,53 & 0,36 & 7,76 & 1,00 & 0,64 \\
\hline 2 & Середня кількість зупинок Т3, с & 0,59 & 0,97 & 0,57 & 1,00 & 0,03 \\
\hline 3 & Середня швидкість, км/год. & 26,57 & 0,63 & 42,38 & 1,00 & 0,37 \\
\hline 4 & Середній час простою ТЗ, с & 11,55 & 0,35 & 4,02 & 1,00 & 0,65 \\
\hline 12 & Середній час у заторі всіх Т3, с & 15,52 & 0,39 & 6,05 & 1,00 & 0,61 \\
\hline 16 & Максимальна довжина затору, м & 104,83 & 0,08 & 7,98 & 1,00 & 0,92 \\
\hline 18 & Емісія $\mathrm{CO}$, гр. & 257 & 0,25 & 63,95 & 1,00 & 0,75 \\
\hline
\end{tabular}

\section{ОБГОВОРЕННЯ РЕЗУЛЬТАТІВ ДОСЛІДЖЕННЯ}

Виконаний аналіз зарубіжних та вітчизняних літературних джерел, а також аналіз результатів моделювання за створеними імітаційними моделями, дозволив авторам сформулювати основні переваги кільцевих перетинів у порівнянні з іншими типами перетинів в одному рівні. Кільцеві перетини:

- забезпечують (при відповідних значеннях і співвідношеннях інтенсивностей транспортних потоків) високу пропускну здатність перехрестя;

- не вимагають додаткових витрат на світлофорне регулювання руху;

- мають меншу кількість розосереджених конфліктних точок;

- забезпечують зниження швидкість руху під час проїзду перехрестя;

- за рахунок невеликих кутів злиття, поділу та перетину транспортних потоків, сприяють зниженню аварійності та тяжкості дорожньо-транспортних пригод;

- мають невеликі втрати часу через зупинки;

- забезпечують кращі умови руху для виконання лівих поворотів;

- вимагають невеликих капітальних витрат на будівництво;

- здійснюють менший негативний вплив на навколишнє середовище.

Як правило схема руху на перехресті із кільцевим рухом є більш простою і зрозумілою водіям;

Радарна діаграма відносних показників та загальна характеристика ефективності організації дорожнього руху на перехресті вул. Набережна Заводська - вул. Павлова наведена на рисунках 15 та 16 відповідною. Значення запропонованого авторами комплексного показника ефективності (1) для кільцевого руху становить 1,00 , а для світлофорного - 0,34, таким чином загальна ефективність запропонованих рішень для обраного об’єкту дослідження склала 66\%.

$$
K_{\text {світлофорний рух }}^{\text {КОмП }}=\sqrt[7]{0,36 \cdot 0,97 \cdot 0,63 \cdot 0,35 \cdot 0,39 \cdot 0,08 \cdot 0,25}=0,34 .
$$




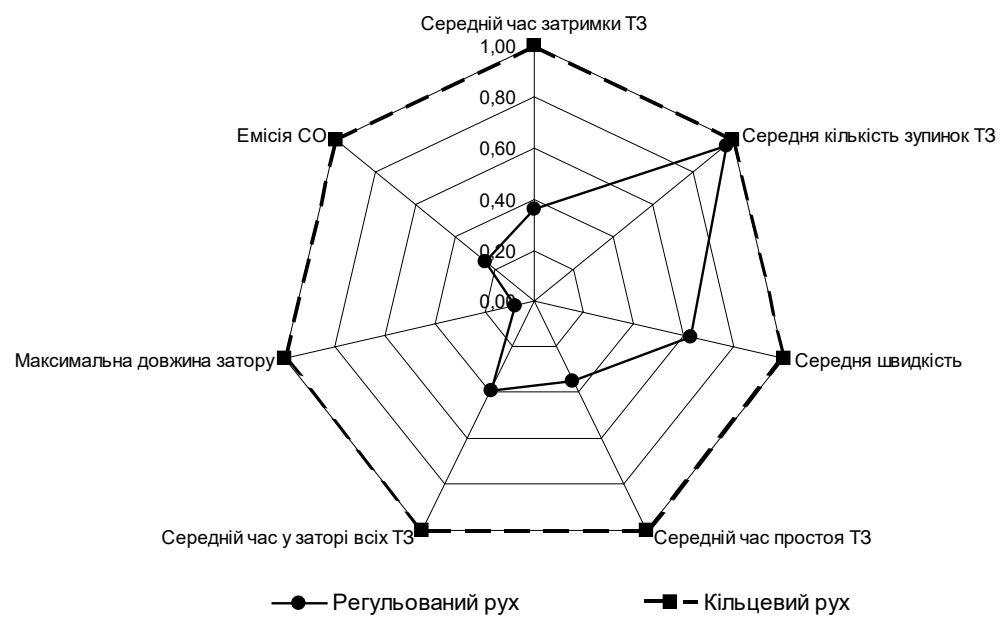

Рисунок 15 - Радарна діаграма відносних показників ефективності організації дорожнього руху

Обрані показники ефективності (Таблиця 4) можуть мати нерівномірну значущість під час прийняття остаточних рішень щодо вибору варіанту організації дорожнього руху. Таким чином виникає проблему у їх ранжуванні (або визначенні вагових коефіцієнтів). Таким чином структура запропонованого критерію (1) може набути наступного виду:

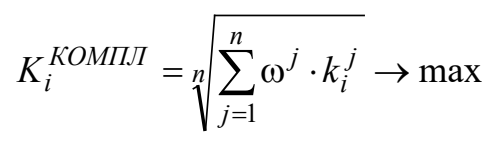

де $\omega^{j}-$ ваговий коефіцієнт $j$-го показника ефективності (для визначення числових значень $\omega^{j}$ автори планують найближчим часом залучити «експертів»- спеціалістів, які мають практичний досвід вирішення задач з організації дорожнього руху та створенні транспортних моделей у середовище VISSIM).

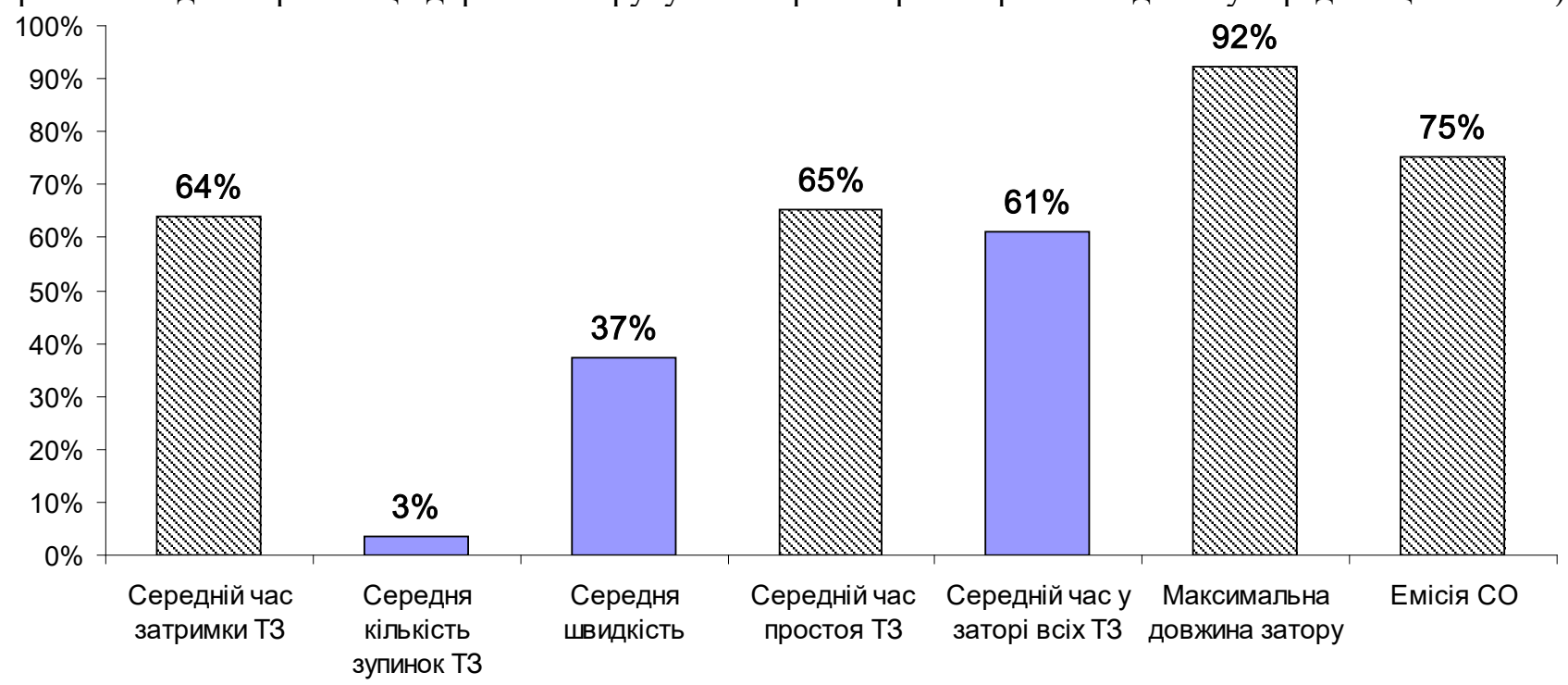

Рисунок 16 - Ефективність запровадження кільцевого руху на перехресті вул. Набережна Заводська - вул. Павлова

\section{ВИСНОВКИ}

В сучасних умовах одним із найбільш дієвих методів зниження аварійності та запобігання ДТП безпосередньо на перехрестях $є$ облаштування сучасних кільцевих перетинів малого і середнього діаметрів. Виконано аналіз зарубіжного досвіду щодо ефективності запровадження кільцевого руху, наведені основні елементи сучасного кільцевого перетину. У якості об'єкту дослідження на ВДМ м. 
Дніпро було обране перехрестя вул. Набережна Заводська - вул. Павлова. Розроблені дві імітаційні транспортні моделі перехрестя (із регульованим та кільцевим рухом) у програмному середовищі PTV VISSIM. Результати моделювання, засвідчують, що застосування кільцевого руху сприяє підвищенню ефективності руху за всіма обраними показниками з діапазоні від 3\% до 92\%. Значення запропонованого авторами комплексного показника ефективності для кільцевого руху становить 1,00 , а для світлофорного - 0,34, таким чином загальна ефективність запропонованих рішень для обраного об'єкту дослідження склала $66 \%$.

\section{ПЕРЕЛІК ДЖЕРЕЛ ПОСИЛАННЯ}

1. Таран И.А., Новицкий А.В., Литвин В.В. Анализ возможностей использования программного обеспечения PTV VISION VISSIM для моделирования транспортных и пешеходных потоков. Вісник СНУ ім. В. Даля. 2015. №2 (219). С. 136-140.

2. Системологія на транспорті. Організація дорожнього руху / Гаврилов Е.В. та ін.; за ред. М.Ф. Дмитриченка. Київ. 2007. 452 с.

3. Організація та регулювання дорожнього руху: підручник / Бакуліч О.О. та ін.; за ред. В.П. Поліщука. Київ. 2016. 467 с.

4. Патрульна поліція, статистика [Електронний ресурc]. URL: https: // patrol.police.gov.ua/statystyka (Дата звернення: 07.11.19).

5. Kennedy J. (2005). Review of Accident Research at Roundabouts. Transport Research Laboratory (TRL Limited), Wokingham, Berkshire. 2005. 14.

6. What roundabout design provides the highest possible safety? (2000) Nordic Road \& Transport Research. No2, 17-21.

7. Taekratok T. (1998). Modern roundabouts for Oregon. Oregon Department of Transportation. 124.

8. Roundabouts: An Informational Guide. (2000). Federal Highway Administration. Publication No FHWA-RD-00-67. 277.

9. Управління дорожнім рухом на регульованих перехрестях у містах: монографія / Форнальчик Є.Ю., Могила І.А., Трушевський В.Е., Гілевич В.В.; за ред. Є. Ю. Форнальчика. Львів. 2018. 236 с.

10. Форнальчик Є.Ю., Гілевич В.В. Порівняльна характеристика деяких показників проїзду регульованих і нерегульованих перехресть. Вісник ХНАДУ. 2010. №50. С. 48-51.

\section{REFERENCES}

1. Taran I.A., \& Noviczkij A.V., \& Litvin V.V. (2015). Analiz vozmozhnostej ispolzovaniya programmnogo obespecheniya PTV VISION VISSIM dlya modelirovaniya transportnykh i peshekhodnykh potokov. Visnik SNU im. V. Dalya.\#2 (219). 136-140.

2. Sistemologiya na transporti. Organizacziya dorozhnogo rukhu (2007). Gavrilov E.V. ta in.; za red. M.F. Dmitrichenka. 452.

3. Organizacziya ta regulyuvannya dorozhnogo rukhu: pidruchnik (2016). Bakulich O.O. ta in.; za red. V.P. Polishhuka. 467.

4. Patrulna policziya, statistika [Elektronnij resurs]. URL: https:// patrol.police.gov.ua/statystyka (Data zvernennya: 07.11.19).

5. Kennedy J. (2005). Review of Accident Research at Roundabouts. Transport Research Laboratory (TRL Limited), Wokingham, Berkshire. 2005. 14.

6. What roundabout design provides the highest possible safety? (2000) Nordic Road \& Transport Research. No2, 17-21.

7. Taekratok T. (1998). Modern roundabouts for Oregon. Oregon Department of Transportation. 124.

8. Roundabouts: An Informational Guide. (2000). Federal Highway Administration. Publication No FHWA-RD-00-67. 277.

9. Fornalchik Ye.Yu., \& Mogila I.A., \& Trushevskij V.E., \& Gilevich V.V. (2018). Upravlinnya dorozhnim rukhom na regulovanikh perekhrestyakh u mistakh: monografiya. 236.

10. Fornalchik Ye.Yu., \& Gilevich V.V. (2010). Porivnyalna kharakteristika deyakikh pokaznikiv proyizdu regulovanikh i neregulovanikh perekhrest. Visnik KhNADU. 48-51. 


\section{Litvin., I. Taran, K. Kononenko. Substantiating the efficiency of circular traffic use in the context of road network in Dnipro City within software environment PTV VISSIM.}

Currently, arrangement of modern circular intersections of small- and medium-size diameters is among the most efficient methods to improve accident record and prevent incidents right within the crossings. The decreased incident rates within such crossings can be explained by massive reduction of the number of conflict points; geometrical parameters resulting in significant velocity decrement; and the improved pedestrian traffic. The world practices have been analyzed as for the circular traffic implementation; basic components of the circular intersection have been listed; and comparative analysis of the modern circular crossings and classic circular crossings has been performed.

Intersection of Naberezhna Zavodska Street-Pavlov Street intersection in Dnipro City has been selected as a test object within a road network with substantiation of the selection criteria. Traffic intensity at the intersection has been obtained with the help of full-scale observations for morning rush hour (i.e. 7 a.m.-8 a.m.). Software product PTV VISSIM 11 has been applied as the modeling tool. According to the algorithm, proposed by the authors, two traffic simulators of Naberezhna Zavodska Street-Pavlov Street intersection have been developed with control traffic and circular traffic. Qualitative analysis of the modeling results has helped conclude that control traffic factors into major traffic jams. The authors have selected a list involving the seven indices (i.e. average delay time; average stop number; average velocity; average idle time; average period of all the vehicles passed in the traffic jam; maximum length of the jam; and $\mathrm{CO}$ emission) for further analysis being the most important to evaluate efficiency of circular traffic implementation. Their absolute values resulting from the modeling as well as calculated relative values have been represented. The modeling results mean that circular traffic is more favourable to improve traffic according to each selected index within the range of 3\% - 92\%. Value of the proposed complex parameter of the circular traffic efficiency is 1.00; in terms of traffic light - the value is 0.34 . Thus, total efficiency of the proposed solutions for the selected object is $66 \%$.

The efficiency indices may be of different importance while making final decision concerning traffic arrangement involving their ranging (or determination of the weight coefficients). In the near future, the authors are going to involve experts, i.e. specialists who are experienced in solving problems as for the traffic arrangement and development of traffic models within VISSIM environment.

Key-words: road network, traffic safety, conflict points, circular crossing, simulation, traffic jam length, average velocity, delay time, PTV VISSIM.

ЛИТВИН Вадим Вікторович, старший викладач кафедри «Управління на транспорті», Національний технічний університет «Дніпровська політехніка», e-mail: litvin.v.v.79@gmail.com. http://orcid.org/0000-0002-1572-9000.

ТАРАН Ігор Олександрович, доктор технічних наук, професор, завідувач кафедри «Управління на транспорті», Національний технічний університет «Дніпровська політехніка», e-mail: taran7077@gmail.com. http://orcid.org/0000-0002-3679-2519.

КОНОНЕНКО Кристина Сергї̈на, студентка кафедри «Управління на транспорті», Національний технічний університет «Дніпровська політехніка», e-mail: kristina.serdyuk97@gmail.com.

Vadim LITVIN, senior lecturer of Transport Management Department, National Technical University "Dnipro Polytechnic", e-mail: litvin.v.v.79@gmail.com. http://orcid.org/0000-0002-1572-9000.

Igor TARAN, Doctor of Science in Technology, Professor, Head of Transport Management Department, National Technical University “Dnipro Polytechnic”, e-mail: taran7077@gmail.com. http://orcid.org/0000-0002$\underline{3679-2519 .}$.

Kristina KONONENKO, student of Transport Management Department, National Technical University "Dnipro Polytechnic", e-mail: kristina.serdyuk97@gmail.com. 